\title{
PARTISIPASI MASYARAKAT DALAM PENGEMBANGAN EKOWISATA PADA KAWASAN TAMAN WISATA ALAM TANJUNG BELIMBING KECAMATAN PALOH KABUPATEN SAMBAS
}

\author{
Community Participation In The Development of Ecotourism In Tanjung Belimbing Natural \\ Tourism Area Of Paloh Distric, Sambas Distric
}

\author{
Elisca, Muhammad Idham, Iskandar \\ Fakultas Kehutanan Universitas Tanjungpura Jalan Imam Bonjol Pontianak 78124 \\ Email: syahumare@yahoo.com
}

\begin{abstract}
Paloh is a coastal area that has the potential to apply the concept of community-based ecotourism. Tanjung Belimbing Nature Tourism Park is a Nature Tourism Park area that has a beautiful natural panorama with the potential of plants and wildlife that attracts tourists, making the community develop into an area that is needed for the development of the area as an ecotourism area. The research objective is to discuss the level of community participation in the development of the Tanjung Belimbing TWA region as an ecotourism area and also the factors that influence the low level of the community in the process of regional development. The research method uses survey method, through purposive sampling technique with the help of a questionnaire as a research instrument. The results showed the level of community participation $(28.89 \%)$ was classified as high participation rate, (13.33\%) moderate participation rate, and (57.78\%) with low participation rate. Based on the level of participation expressed by Arnstein Participation in the level of participation of the people of Sebubus Village only reached the level of participation Consultation in this family
\end{abstract}

Keywords: Community, Ecotourism, Nature Tourism Parks, Participation

\section{PENDAHULUAN}

Menurut The International Ecotourism Society atau TIES (1991) ekowisata adalah perjalanan wisata ke wilayah-wilayah alami dalam rangka mengkonservasi atau menyelamatkan lingkungan dan memberi penghidupan penduduk lokal. Berdasarkan definisi tersebut, mengindikasikan bahwa kegiatan ekowisata adalah kegiatan perjalanan wisata alam dengan minat khusus, yang dilakukan dengan memenuhi kaidah-kaidah pelestarian lingkungan.

Kecamatan Paloh mrupakan salah satu daerah pesisir yang menyimpan banyak potensi wisata terutama potensi wisata bahari yang menawan. Dengan panjang garis pantai yang membentang sepanjang kurang lebih $63 \mathrm{~km}$ membuat Paloh menjadi salah satu daerah dengan pesisir pantai terpanjang di Indonesia (Sabahan 2017). Potensi tersebut dapat dibuktikan dengan mulai berkembangnya beberapa kawasan wisata yang menawarkan keindahan alam berupa pantai yang hingga kini masih terus berkembang kearah wisata yang lebih maju salah satunya adalah Taman Wisata Alam Tanjung Belimbing.

Menurut UU No.5 tahun 1990 taman wisata alam adalah kawasan hutan konservasi yang bisa 
dimanfaatkan untuk kegiatan pariwisata dan rekreasi. TWA Tanjung Belimbing merupakan hamparan hutan pantai dan mangrove yang menyimpan potensi keanekaragaman hayati berupa tumbuhan dan satwa yang cukup bervariasi. Hutan Pantai memiliki formasi Cemara Laut (Casuarina equisetifolia), sedangkan hutan mangrove memiliki formasi jenis mangrove, di antaranya adalah Bakau (Rhizopora sp). Sementara untuk satwa, potensi yang dimiliki kawasan ini di antaranya adalah Cekakak Sungai, Buaya Muara (Crocodylus porosus), Penyu Hijau (Chelonia mydas), Penyu Sisik (Eretmochelys imbricata) dan Bekantan (Nasalis larvatus).

Oktaviani (2018), menyebutkan partisipasi masyarakat lokal dalam pengelolaan wisata bahari di pantai Semawang kelurahan Sanur kelod menunjukkan bahwa masyarakat ikut terlibat dalam pengelolaan wisata dikarenakan untuk meningkatkan tarap hidup. Adanya motivasi untuk meningkatkan kesejahteraan membuat hubungan saling menguntungkan antara pihak swasta dan masyarakat. Partisipasi tersebut mencakup dalam bidang sosial, budaya, ekonomi, dan lingkungan sementara partisipasi masyarakat dalam pengelolaan wisata bahari menurut Nabila (2018), bahwa adanya keinginan masyarakat untuk berpartisipasi dengan cara mengelola objek wisata dan mendukung potensi wisata untuk menjamin keberhasilan dalam pengelolaan wisata bahari. Hasil penelitian Prasetia (2015) partisipasi masyarakat dalam pengembangan usaha ekowisata berbasis pantai di simpulkan bahwa masyarakat ikut terlibat secara langsung dalam proses pengembangan usaha ekowisata dengan cara memahami tentang proyek yang berhubungan dengan kegiatan pengembangankawasan. Faktor pendorong dan penghambat dalam penelitaian ini adalah faktor internal berupa kesadaran dari masyarakat dan faktor penghambat adalah aparat birokrasi yang kurang mensosialisasikan program pengembangan tersebut.

Pengembangan suatu kawasan wisata juga tergantung pada hal yang dimiliki kawasan tersebut untuk dapat ditawarkan kepada wisatawan sehingga partisipasi dan peran serta masyarakat sangat diperlukan. Menurut Poerbakawatja, (1981) partisipasi adalah gejala demokrasi dimana seseorang diikutsertakan dalam perencanaan serta pelaksanaan dari segala sesuatu yang berpusat pada kepentingan, dan juga tanggung jawab sesuai dengan tingkat kematangan dan kewajibannya. Keterlibatan masyarakat dalam proses menarik minat wisatawan sangat mempengaruhi eksistensi TWA Tanjung Belimbing sebagai salah satu daerah kawasan wisata alam yang berbasis ekowisata. Dengan potensi yang sangat besar seharusnya partisipasi dari masyarakat setempat tak hanya semata untuk turut menjaga kelestarian kawasan saja, namun penyediaan jasa dan layanan wisata kepada wisatawan dinilai sangat penting dan menjadi suatu 
nilai tambah bagi penduduk sekitar kawasan. Sehingga penulis tertarik untuk melakukan penelitian lebih lanjut mengenai "Partisipasi Masyarakat Dalam Pengembangan Ekowisata Pada Kawasan TWA Tanjung Belimbing, Kecamatan Paloh Kabupaten Sambas"

Tujuan dilakukan penelitian ini adalah untuk mendapatkan data dan informasi tentang partisipasi masyarakat dalam upaya pengembangan ekowisata pada Kawasan Taman Wisata Alam Tanjung Belimbing Kecamatan Paloh, Kabupaten Sambas.

Adapun manfaat yang diperoleh dari hasil penelitian ini berupa data dan informasi yang berguna bagi semua kalangan terutama bagi peneliti selanjutnya yang akan melakukan penelitian yang serupa serta secara serius ingin mengamati aspek sosial masyarakat, serta memberikan masukan dan manfaat bagi instansi terkait sehingga hasil penelitian ini dapat menjadi acuan instansi dalam membuat kebijakan yang berkaitan dengan pembangunan kawasan sehingga, hubungan antara aspek ekonomi, sosial, dan budaya dapat berjalan secara seimbang.

\section{METODE PENELITIAN}

Penelitian ini merupakan penelitian yang bersifat Deskriptif Kuantitatif dimana mendeskripsikan suatu fenomena berdasarkan data kuantitatif. Penelitian ini dilaksanakan di Desa Sebubus Kecamatan Paloh, Kabupaten Sambas, dengan waktu penelitian dilaksanakan pada tanggal 25 Juli 2019 sampai 20 Agustus 2019. Objek dalam penelitian ini adalah masyarakat Desa Sebubus Kecamatan Paloh Kabupaten Sambas, yang terdiri dari dua dusun yaitu Dusun Melati dan Dusun jeruju. Penelitian ini dilakukan dengan menggunakan metode survey dengan teknik wawancara langsung kepada responden yang telah ditentukan secara purposive sampling. Jenis data yang dikumpulkan dalam penelitian ini adalah data atau informasi yang berhubungan dengan partisipasi masyarakat terhadap pengembangan ekowisata pada kawasan TWA Tanjung Belimbing dengan alat bantu berupa kuesioner. Jumlah responden dalam penelitian ini sebanyak 90 responden dari jumlah populasi sebanyak 808 orang dengan kriteria: masyarakat Dusun Melati dan Dusun Jeruju, berdomisili kurang lebih 5 tahun, berusia minimal 17 tahun, sehat jasmani dan rohani.

Teknik pengambilan sampel dilakukan secara purposive sampling menggunakan rumus Slovin dengan persen kelonggaran $10 \%$ adalah sebaai berikut :

$n i=\frac{N i}{1+\sum N i . e^{2}}$

Keterangan :

ni = jumlah samlpel ke $\mathrm{i}$

$\mathrm{Ni}=$ Jumlah populasi ke $\mathrm{i}$

$\sum \mathrm{Ni}=$ Total Pupulasi $\mathrm{N}$

$\mathrm{e}=$ batas kesalahan (peresen kelonggaran 10\%)

Beberapa narasumber atau responden dalam penelitian ini dapat di lihat pada tabel dibawah: 
Tabel 1. Daftar Narasumber atau Responden Fokus Penelitian (Interviewees list or Respondents focused on research)

\begin{tabular}{lll}
\hline No. & Narasumber/Responden & Jumlah (orang) \\
\hline 1. & Instansi BKSDA & 1 \\
2. & Kepala Desa Sebubus & 1 \\
3. & Masyarakat Dusun & \\
& 1). Melati & 45 \\
& 2). Jeruju & 45 \\
\hline Jumlah & & 92 \\
\hline
\end{tabular}

\section{Variabel Penelitian}

a. Variabel Terikat

Variabel terikat adalah variabel yang dipengaruhi oleh variabel bebas menurut (Silaen dan widiono,2013) variabel terikat adalah variabel yang nilai besarannya tergantung dari variabel bebas. Variabel terikat dalam penelitian ini adalah partisipasi masyarakat Desa Sebubus dalam pengembangan ekowisata.

\section{b. Variabel Bebas}

Variabel bebas adalah variabel yang memiliki pengaruh atau yang dapat mempengaruhi variabel lain. Dalam penelitian ini, yang menjadi variabel bebas mengenai partisipasi masyarakat Desa Sebubus dalam pengembangan ekowisata pada kawasan TWA Tanjung belimbing Kecamatan Paloh Kabupaten Sambas adalah pengetahuan dan pendapatan.

\section{Analisis Data}

Analisis data yang digunakan dalam penelitian ini adalah analisis deskriptif dan analisis inferensial, dimana analisis deskriptif adalah analisis yang digunakan untuk mendeskripsikan maupun menggambarkan data yang telah dikumpulkan, tanpa bermaksud untuk membuat kesimpulan yang berlaku umum atau generalisasi Sugiyono (2014). Sedangkan analisis inferensial adalah analisis data yang menggunakan uji statistik inferensial (statistic induktif) dengan tujuan menarik kesimpulan yang berlaku umum atau generalisasi.

Data partisipasi didapat dari hasil jawaban responden melalui kuesioner dimana data tersebut masih bersifat data kualitatif yang kemudian dirubah ke dalam bentuk data kuantitatif dengan menggunakan aplikasi Microsoft Excel 2010. Jawaban masyarakat yang tertuang didalam kuesioner di beri skor 4 apabila memilih jawaban A, skor 3 apabila memilih jawaban B, skor 2 apabila memilih jawaban $\mathrm{C}$, dan skor 1 apabila masyarakat memilih jawaban D.

Hasil tiap point pertanyaan dengan masing-masing bobot skor kemudian dijumlahkan dan total bobot nilai per tiap individu di buat tabel frekuensi dengan tiga kategori tinggi, sedang, rendah dengan menggunakan perhitungan rumus Convidence Interval (Selang Kepercayaan) dengan bantuan Microsoft Excel sebagai berikut :

$\mathrm{CI}=\mathrm{X} \pm \mathrm{t} . \mathrm{Sx}$

Keterangan : 
$\mathrm{CI}=$ Convidence Interval (selang

Kepercayaan)

$\mathrm{X}=$ Nilai Tengah (rata-rata $\mathrm{X}$ ).

$\mathrm{t}=\mathrm{t}$ tabel $(88 \%)$.

$\mathrm{Sx}=$ Standar error

$S x=\sqrt{1-f\left(\frac{V r}{n}\right)}$

f : Intensitas sampling $(0,04)$.

$\mathrm{Vr} \quad$ : Varians $\left(\mathrm{Sd}^{2}\right)$

n : Jumlah Sample.

Dengan ketentuan sebagai berikut :

1. Kategori Tinggi, jika $\mathrm{CI}=\geq \mathrm{X}+\mathrm{t}$. Sx

2. Kategori Sedang, jika $C I=X-t$. $S x$ $\mathrm{s} / \mathrm{d}<\mathrm{X}+\mathrm{t}, \mathrm{Sx}$

3. Kategori Rendah, jika $\mathrm{CI}=<\mathrm{X}-$ t.Sx

a. Analisis Inferensial

Analisis inferensial dalam penelitian ini menggunakan uji statistik non parametric korelasi Kendall Tau dengan tujuan untuk melihat hubungan antara variabel terikat (partisipasi masyarakat dalam pengembangan ekowisata pada kawasan TWA Tanjung Belimbing) terhadap variabel bebas yaitu (tingkat pendidikan, pengetahuan dan pendapatan). Analisis data dengan uji korelasi Kendall Tau menggunakan total dari tiap bobot skor data kualitatif dari masing-masing variabel pengamatan selanjutnya, hasil pengamatan dianalisis dengan menggunakan uji korelasi Kendall Tau dengan rumus sebagai berikut

$\tau=\frac{\sum A-\sum B}{\frac{N(N-1)}{2}}$

Keterangan :

$\tau=$ Koefesien Korelasi Kendall Tau yang besarnya $(-1<0<1)$
$\mathrm{A}=$ Jumlah rangkaian atas

$\mathrm{B}=$ Jumlah rangkaian bawah

$\mathrm{N}=$ Jumlah gagasan sampel

b. Uji Validitas

Uji validitas yang digunakan dalam penelitian ini berdasarkan teknik uji korelasi Person dengan bantuan SPSS 16.0 for windows data yang ada terdiri dari dua variabel yaitu variabel $\mathrm{x}$ dan variabel y sehingga untuk mengetahui indeks validitasnya dilakukan dengan mengkorelasikan dua variabel tersebut dengan rumus :

$r_{x y}=\frac{N\left(\sum X Y\right)-\left(\sum X \cdot \sum Y\right)}{\sqrt{\left\{N \sum X^{2}-(X)^{2}\right\}\left\{N \sum Y^{2}-\left(\sum Y\right)^{2}\right\}}}$

Keterangan :

$r_{x y}=$ Koefisien korelasi item total

(bivanate pearson)

$\mathrm{N}=$ Jumlah responden

$\mathrm{X}=$ Skor item pertanyaan

$\mathrm{Y}=$ Skor item total

Nilai signifikasi $<0,05$ maka item valid, jika signifikasi > 0,05 maka item tidak valid.

\section{c. Uji Reliabilitas}

Untuk menguji reliabilitas instrument (kuesioner) dalam penelitian ini, peneliti menggunakan bantuan program SPSS. Uji reliabilitas dihitung dengan rumus sebagai berikut:

ri $=\left[\frac{k}{(k-1)}\right]\left[-\frac{V i}{(V t)}\right.$

Keterangan:

ri $=$ Realibilitas internal seluruh komponen

$\mathrm{k}=$ Banyaknya butir pertanyaan

$\mathrm{Vi}=$ Jumlah varians jawaban item ke- $\mathrm{i}$

$\mathrm{Vt}=$ Nilai varians total

Menurut Priyatno (2010), jika reliabilitas kurang dari 0,6 (kurang 
baik), sedangkan realibiltas 0,7 (dapat diterima) dan diatas 0,8 (baik).

\section{HASIL DAN PEMBAHASAN}

Partisipasi yang tinggi didalam suatu lingkup masyarakat sangat memungkinkan untuk terciptanya keselarasan antara pemerintah selaku pemberi keputusan terhadap masyarakat selaku penerima keputusan, hubungan tersebut akan lebih baik apabila masyarakat ikut terlibat secara aktif dalam setiap tahapan partisipasi sebagaimana yang telah di kemukakan oleh Cohen dan Uphoff (1977) tahapan partisipasi masyarakat dibagi menjadi 4 tahapan penting yaitu, tahap pengambilan keputusan, tahap pelaksanaan, tahap menikmati hasil, dan tahap evaluasi. Apabila seluruh tahapan dijalani dengan baik secara bersamasama maka telah terjadi pembagian ulang kekuasaan yang adil.

Tingkat partisipasi masyarakat dalam pengembangan ekowisata pada kawasan TWA Tanjung Belimbing Kecamatan Paloh, Kabupaten Sambas diuraikan pada Tabel 2 sebagai berikut:

Tabel 2. Frekuensi Tingkat Partisipasi Masyarakat dalam Pengembangan Ekowisata. (Frequency level of community participation in development of ecoturism)

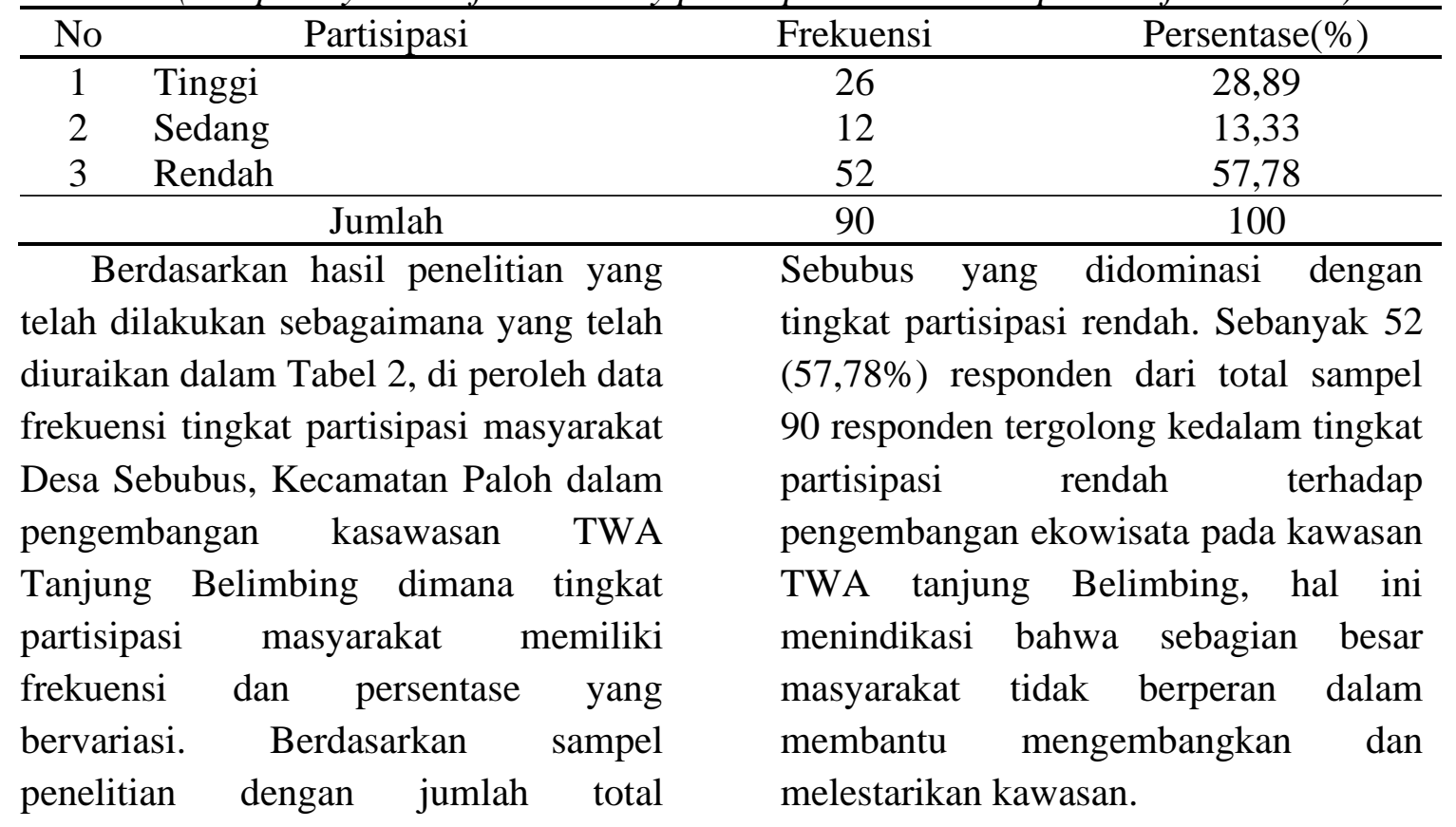
responden sebanyak 90 orang terdapat 26 responden $(28,89 \%)$ memiliki tingkat partisipasi tinggi, sebanyak 12 $(13,33 \%)$ orang responden memiliki tingkat partisipasi sedang, dan sebanyak 52 (57,78) responden tergolong ke dalam tingkat partisipasi rendah.

Data diatas menunjukkan tendensi dari tingkat partisipasi masyarakat Desa

Sherry R. Arnstein menyebutkan bahwa terdapat 8 tangga imajiner yang menjadi pedoman untuk melihat sejauh mana partisipasi didalam lingkungan masyarakat berjalan. Terdapat 8 tingkatan yang yang disebut The Ladder of Citizen Participation (tangga partisipasi publik) yang mengurut dari bawah ke atas dimana 
pada setiap tangga mengandung arti yang berbeda Manipulation (manipulasi), Therapy (memulihkan), Consultation, (merundingkan), Placation (mendiamkan), Partnership (bekerjasama), Delegated Power (pendeglagasian kekuasaan), Citizen Control (kontrol publik) Tingkat partisipasi 8 tangga $\mathrm{R}$. Arnstein berdasarkan skoring menurut (Ningrum 2019)

Tabel 3. Teori Partisipasi 8 Tangga R. Arnstein. (R.Arnstein participation theory)

\begin{tabular}{llc}
\hline No & Tingkat partisipasi & Skor \\
\hline 1 & Manipulasi & $1980-2722$ \\
2 & Terapi & $2723-3464$ \\
3 & Pemberitahuan & $3465-4206$ \\
4 & Konsultasi & $4207-4948$ \\
5 & Penentraman & $4949-5690$ \\
6 & Kemitraan & $5691-6432$ \\
7 & Pelimpahaan Kekuasaan & $6433-7174$ \\
8 & Kontrol Masyarakat & $7145-7916$ \\
\hline
\end{tabular}

Partisipasi masyarakat Desa Sebubus Kecamatan Paloh Kabupaten Sambas, dalam membantu pengembangan ekowisata pada kawasan TWA Tanjung Belimbing apabila dilihat berdasarkan teori partisipasi 8 tangga (R. Arnstein,1968) dapat disimpulkan bahwa tingkat partisipasi masyarakat di Desa Sebubus dalam pengembangan ekowisata kawasan TWA Tanjung Belimbing termasuk ke dalam tingkat partisipasi rendah dan berada pada level tangga "Consultation" dimana berdasarkan hasil skoring yang dirincikan didapat total skor pertanyaan tiap responden yang telah ditabulasikan dengan menggunakan microssoft excel yaitu berjumlah 4726. Apabila dibandingkan dengan tangga partisipasi yang dikemukakan oleh Arnstein angka tersebut tergolong dalam tangga partisipasi "Consultation" yang berarti pada tangga ini, dapat diketahui tidak adanya partisipasi yang bersifat nyata bentuk partisipasi yang terjadi hanya bersifat "delusive", antara masyarakat dengan pihak instansi terkait. Pada level tangga ini telah terjalin komunikasi yang bersifat dua arah antara Instansi KSDA Resot Paloh dengan masyarakat setempat, dimana masyarakat diundang dan diberi informasi, sudah ada penampungan aspirasi, telah ada aturan pengajuan usulan, serta telah ada harapan bahwa aspirasi masyarakat akan didengarkan tetapi masih belum adanya jaminan apakah aspirasi dari masyarakat dilaksanakan.

\section{Faktor yang Mempengaruhi Partisipasi Masyarakat}

Partisipasi menurut Sumaryadi (2005) merupakan peran dan serta seseorang maupun sekelompok orang dalam proses pembangunan dimana hal tersebut dpat diwujudkan dalam bentuk pernyataan maupun dalam bentuk 
kegiatan dengan memberi masukan seperti sumbang pikiran, tenaga, waktu, keahlian, materi berupa modal, serta bersama-sama ikut memanfaatkan dan menikmati hasil pembangunan tersebut.

Dalam partisipasi masyarakat tedapat bebrapa faktor hambatan yang mempengaruhi tingkat partisipasi masyarakat baik itu faktor internal maupun faktor eksternal. Dimana kedua faktor tersebut dapat menjadi indikasi keberhasilan program maupun menjadi suatu penghambat berjalannya suatu program (Firmansyah, 2009). Namun, dalam penelitian ini lebih memfokuskan faktor-faktor yang menjadi penghambat dalam partisipasi masyarakat Desa Sebubus, dalam proses pengembangan potensi kawasan TWA Tanjung Belimbing.

Berdasarkan hasil pengamatan yang dilakukan terhadap 90 orang responden, diketahui ada beberapa masalah internal dan eksternal secara khusus yang menyebabkan tingkat partisipasi masyarakat Desa Sebubus cenderung rendah terhadap pengembangan kawasan TWA Tanjung Belimbing sedangkan, potensi kawasan TWA Tanjung Belimbing sangat potensial untuk dikembangkan menjadi suatu kawasan wisata yang berwawasan lingkungan. Potensi wisata tersebut apabila diimbangi dengan partisipasi masyarakat tentu akan jauh lebih memberikan dampak yang positif demi keberhasilan pengelolaan kawasan. Namun, pada kenyataannya masyarakat Desa Sebubus masih belum memanfaatkan peluang tersebut untuk membangun desa mereka kearah yang lebih maju hal tersebut sangat bertolak belakang dengan Desa Temajok yang saat ini tumbuh menjadi Desa Wisatan yang jauh lebih maju di Kecamatan Paloh.

Penyebab rendahnya tingkat partisipasi masyarakt Desa Sebubus dalam pengembangan kawasan TWA Tanjung Belimbing menjadi suatu kawasan ekowisata disebabkan oleh:

a. Komunikasi antar sesama masyarakat dan pemimpin antar sistem sosial

Komunikasi yang dilakukan dengan baik dapat menjembatani hubungan antara masyarakat dengan pemimpin sehingga terjalin komunikasi yang searah. Namun realisasi yang didapat dari hasil penelitian dilapangan diketahui bahwa komunikasi yang terjalin antara pemerintah dan masyarakat sudah terjadi namun tidak begitu intensif sehingga masih terdapat beberapa hal yang sulit untuk dipahami bahkan diterima oleh masyarakat. Sikap defensif dari masyarakat adalah salah satu faktor penyebab tidak intensifnya komunikasi yang terjalin antara pemerintah dan masyarakat sehingga menyebabkan proses sosialisasi tidak dapat berjalan dengan sempurna. Menurut Suroso (2014), masyarakat dengan tingkat komunikasi yang tinggi akan memiliki tingkat partisipasi yang tinggi sedangakan, masyarakat dengan tingkat komunikasi yang rendah hanya sebagian kecil saja yang memiliki tingkat partisipasi yang tinggi. 
Akibat dari proses sosialisasi yang tidak berjalan dengan sempurna ini, menyebabkan terputusnya informasi antara sesama masyarakat yang berdampak pada kurangnya pengetahuan dan pemahaman masyarakat terhadap program yang dilaksanakan oleh pemerintah terkait upaya mengembangkan kawasan TWA Tanjung Belimbing menjadi kawasan ekowisata yang lebih maju.

b. Iklim sosial, ekonomi, politik dan budaya masyarakat

Bertolak ukur berdasarkan hasil penelitian yang telah dilakukan didapatkan hasil yang menunjukan bahwa iklim sosial, ekonomi, politik dan budaya dalam lingkungan masyarakat desa Sebubus masih tergolong rendah hal tersebut disebabkan karena karakteristik masyarakat yang masih tradisional dan cenderung sulit untuk terbuka akan halhal baru. Pernyataan ini didukung dengan rendahnya pengetahuan dan persepsi masyarakat mengenai status kawasan dan pola pemanfaatan kawasan. Tingginya persentase tingkat pendidikan masyarakat yang menempuh pendidikan pada tingkat sekolah menengah atas hingga perguruan tinggi, tidak menjamin masyarakat akan lebih kritis dan apresiatif dalam membantu mengembangkan kawasan TWA tanjung Belimbing sebagai salah satu kawasan ekowisata yang komersil untuk ditawarkan.

\section{c. Kesempatan untuk berpartisipasi}

Kesempatan untuk berpartisipasi menjadi salah satu faktor penting dalam menentukan tinggi, rendahnya tingkat partisipasi masyarakat dimana partisipasi merupakan keikutsertaan masyarakat baik dalam bentuk pernyataan maupun kegiatan (Wardoyo, 1992).

Berdasarkan hasil pengamatan dilapangan, pemerintah/instansi terkait sudah memberikan kesempatan kepada masyarakat untuk berpartisipasi dalam membantu pengembangan kawasan TWA Tanjung Belimbing guna membangun dan melestarikan kawasan. Diluar dari kesempatan berpartisipasi yang telah diberikan pemerintah, terdapat perbedaan latar belakang masyarakat Desa Sebubus yang cenderung dominan berprofesi sebagai seorang petani dan nelayan, sehingga menjadi pemicu rendahnya tingkat partisipasi masyarakat dalam pengembangan kawasan TWA Tanjung Belimbing disebabkan karena perbedaan kepentingan dan waktu yang digunakan untuk berpartisipasi baik secara langsung maupun tidak langsung dalam kegiatan maupun agenda yang diadakan oleh instansi terkait.

d. Kebebasan untuk berprakarsa dan berkreasi

Seperti yang termuat dalam uu bahwa masyarakat dapat bebas mengemukakan pendapat. Begitu pula dalam menumbuhkan partisipasi masyarakat dapat diberi kesempatan untuk berpendapat dalam suatu forum yang dimana pemerintah dapat menjadikan pendapat tersebut sebagai masukan. Sehingga dapat terjalin suatu komunikasi yang baik dan dapat 
menciptakan hubungan yang saling menguntungkan antara pemerintah dan masyarakat.

Bedasarkan hasil wawancara dan pengamatan dilapangan, diketahui bahwa masyarakat Desa Sebubus belum sepenuhnya mampu mengungkapkan buah pikiran merka sendiri sehingga dalam hal ini masyarakat cenderung pasif dalam kegiatan pengembangan kawasan TWA Tanjung Belimbing. Selain itu, masyarakat juga belum memanfaatkan sumber daya dan potensi yang ada di wilayah mereka untuk dikembangkan dalam bentuk kreatifitas. Hal ini bertolak belakang dengan kemajuan sector pariwisata bahari yang ada di Desa Temajok dimana masyarakat setempat sudah mulai memahami akan pentingnya pengembangan kawasan wisata yang ada didaerah mereka guna meningkatkan tarap hidup kearah yang lebih baik.

\section{Hubungan Variabel Terikat dan Variabel Bebas}

Variabel terikat dalam penelitian ini adalah partisipasi masyarakat Desa Sebubus, Kec.Paloh dalam pengembangan ekowisata pada kawasan TWA Tanjung Belimbing sedangkan variabel bebas dalam penelitian ini adalah tingkat pengetahuan, dan tingkat pendapatan. Didalam penelitian ini digunakan analisis inferensial dan uji statistik non paremetrik korelasi Kendall Tau untuk melihat adanya hubungan antara variabel terikat.

Analisis inferensial adalah analisis yang dilakukan dengan menggunakan uji ststistik serta digunakan untuk menganalisis data sampel dengan maksud membuat kesimpulan yang berlaku untuk umum (Idrus,2009). Dari hasil uji statistik korelasi Kendall Tau dapat diketahui hubungan antara variabel terikat dan variabel bebas adalah sebagai berikut :

Tabel 4. Hasil uji ststistik Kendall Tau. (Kendall Tau statistical test result)

\begin{tabular}{clcccc}
\hline No & Variabel & N & $\begin{array}{c}\text { Correlation } \\
\text { Coefficient }\end{array}$ & $\begin{array}{c}\text { Sikap } \\
\text { Sig. } \\
\text { (2-tailed) }\end{array}$ & Keterangan \\
\hline 1 & Tingkat pengetahuan & 90 & 0,290 & 0,000 & Signifikan \\
2 & Tingkat pendapatan & 90 & $-0,034$ & 0,662 & Tidak Signifikan \\
\hline
\end{tabular}

Sumber : Analisis Data Primer 2019

a. Hubungan antara partisipasi masyarakat dengan tingkat pengetahuan

Hasil analisis korelasi melalui uji ststistik Kendall Tau didapat hunungan antara partisipasi masyarakat dalam pengembangan kawasan ekowisata TWA Tanjung Belimbing terhadap tingkat pengetahuan memiliki hubungan yang signifikan. Data tersebut diperoleh dari nilai Sig.(2-tailed) 0,000 lebih kecil dari taraf signifikan $5 \%$ atau nilai sig. $0,000<0,05$ dengan keofisien positif sebesar 0,290. Tingkat pengetahuan masyarakat Desa Sebubus terhadap partisipasi dalam pengembangan kawasan TWA Tanjung Belimbing dapat di katakana memiliki pengaruh 
nyata dimana sebanyak 69 responden dengan persentase sebesar $(76,67 \%)$ memiliki tingkat pengetahuan sedang.

b. Hubunga antara partisipasi
masyarakat dengan
pendapatan

Hasil uji statistic Kendall Tau hubungan antara partisipasi masyarakat dalam pengembanga kawasan TWA Tanjung Belimbing terhadap pendapatan masyarakat tidak memiliki hubungan yang signifikan dimana hasil tersebut dapat di lihat dari hasil nilai Sig.(2-tailed) 0,662 lebih kecil dari taraf signifikan 5\% atau nilai Sig 0,662 < 0,05 dengan koefisen korelasi negative sebesar 0,034. Sehingga dapat disimpulkan bahwa hubungan antara partisipasi masyarakat tidak memiliki hubungan dalam pengembangan kawasan TWA Tanjung Belimbing sebagai kawasan ekowisata. Data tersebut bertolak belakang dengan pernyataan (lingani et,al 2011) yang menyatakan bahwa pendapatan mempengaruhi partisipasi masyarakat. Berdasarkan hasil pengamatan dilapangan dapat diketahui bahwa pendapatan masyarakat Desa Sebubus cenderung sedang dengan persentase $(72,22 \%)$ dimana sebagian besar masyarakat bemata pencahrian sebagai petani dan nelayan.

\section{KESIMPULAN}

1. Sebanyak 26 orang responden $(28,89 \%)$ memiliki tingkat partisipasi tinggi, sebanyak 12 orang responden $(13,33 \%)$ memiliki tingkat partisipasi sedang, dan sebanyak 52 orang responden $(57,78 \%)$ memiliki tingkat partisipasi yang cenderung rendah terhadap pengembangan ekowisata pada kawasan TWA Tanjung Belimbing.

2. Masyarakat di Desa Sebubus Kecamatan Paloh Kabupaten Sambas belum berpartisipasi dalam upaya pengembangan ekowisata pada kawasan TWA Tanjung Belimbing. Apabila dilihat berdasarkan teori partisipasi yang dikemukakan oleh Sherry R. Arnstein kekuatan partisipasi masyarakat Desa Sebubus dalam pengembangan ekowisata pada kawasan TWA Tanjung Belimbing Paloh hanya mencapai tangga partisipasi Consultation. Pada tangga partisipasi ini komunikasi telah bersifat dua arah, tapi masih bersifat partisipasi yang ritual. Sudah ada penjaringan aspirasi, namun belum adanya jaminan aspirasi tersebut akan dilaksanakan. Sehingga bentuk partisipasi yang terjadi hanya sebatas penyediaan jasa transportasi dan penginapan. Masyarakat masih belum memanfaatkan secara optimal potensi kawasan untuk dikembangkan ke arah yang lebih maju.

3. Adapun faktor yang mempengaruhi partisipasi masyarakat dalam pengembangan ekowisata pada kawasan TWA Tanjung Belimbing di sebabkan karena :

- Komunikasi anatar sesama masyarakat dan pemerintah belum terjalin secara kondusif

- Iklim sosial, ekonomi, politik dan budaya yang masih sederhana 
sehingga mengahambat masyarakat untuk menerima hal baru sehingga partisipasi yang terjadi cenderung rendah.

- Kurangnya kesempatan untuk berpartisipasi yang diakibatkan kesibukan yang berbeda-beda anatar tiap masyarakat.

- Masyarakat masih belum mampu mengapresiasikan ide dalam bentuk kreatifitas sehingga pengembangan kawasan untuk menjadi suatu kawasan ekowisata yang maju tergolong lambat

\section{Saran}

Untuk meningkatkan partisipasi masyarakat serta menumbuhkan kesadaran masyarakat akan pentingnya menjaga dan melestarikan kawasan TWA Tanjung Belimbing, sangat dibutuhkan sosialisasi yang rutin untuk mendorong dan membentuk keinginan berpartisipasi dari masyarakat setempat sehingga pengembangan kawasan dapat berjalan sesuai dengan tujuan dan manfaat yang diharapkan.

\section{DAFTAR PUSTAKA}

Anonim. 1990. Undang-Undang Nomor

5 Tahun 1990 tentang Konservasi Sumberdaya Alam Hayati dan Ekosistemnya.

Anonim. 2015. Peraturan Menteri Lingkungan Hidup dan Kehutanan RI Nomor P.76/MenlhkSetjen/2015 Tentang Kriteria Zona Pengelolaan Taman Nasional dan Blok Pengelolaan Cagar Alam, Suaka Margasatwa, Taman Hutan Raya dan Taman Wisata Alam.
Arnstein SR. 1969. A Ladder of Citizen Participation. JAIP 35(4): 216-224.

Anonim. 2015. Peraturan Menteri Lingkungan Hidup dan Kehutanan RI Nomor P.76/MenlhkSetjen/2015 Tentang Kriteria Zona Pengelolaan Taman Nasional dan Blok Pengelolaan Cagar Alam, Suaka Margasatwa, Taman Hutan Raya dan Taman Wisata Alam.

Cohen, Uphoff. 1977. Rural Development Participation. Cornel University. New York.

Firmansyah S. 2009. Partisipasi Masyarakat. diakses 17-02-2020 http://sacafirmansyah.wordpress.c om/2009/06/05/partisipasimasyarakat/

Fitriah N. 2018. Partisipasi Masyarakat dalam Pengelolaan Wisata Bahari. Studi Pustaka 6(4).

Idrus M. 2009. Metode Penelitian Ilmu Sosial. Yogyakarta: PT Gelora Aksara Pratama.

Oktaviani PD. 2018. Partisipasi Masyarakat Lokal dalam Pengembangan Wisata Bahari Di Pantai Semawang Kelurahan Sanur Kelod. Jurnal Destinasi Pariwisata 6(2) : 341-349.

Prasetia AR. 2015. Partisipasi Masyarakat Dalam Pengembangan Usaha Ekowisata Berbasis Pantai. Administrasi Publik 3(4).

Sabahan ER. 2017. Zonasi Lanskap Ekowisata Pesisir Kecamatan Paloh Kalimantan Barat. E-Jurnal Arsitektur Lansekap 3(1) : 32-38.

Sugiyono. 2014. Metode Penelitian Pendidikan Pendekatan 
Kuantitatif, Kualitatif, dan Kombinasi (Mixed \& Methods). Bandung: Alfabeta.

Sumaryadi I Nyoman. (2005). Perencanaan Pembangunan Daerah Otonomi dan Pemberdayaan Masyarakat. Jakarta: Penerbit Citra Utama.

Suroso H, Hakim A, Noor I. 2014. Faktor-faktor yang Mempengaruhi Partisipasi
Masyarakat Dalam Perencanaan Pembangunan Di Desa Banjaran Kecamatan Driyorejo Kabupaten Gresik. Wacana 17 (1) : 7-15.

Wardoyo. 1992. Pendekatan Penyuluhan Pertyanian Untuk Meningkatkan Partisipasi Masyarakat. Seminar Nasional tanggal 25 September 1990 Bogor. 